\title{
Meningkatkan Pengetahuan Siswa Dalam Penyelenggaraan Pameran Seni Rupa Melalui Metode Demonstrasi Di Kelas XI MIPA 5 SMAN 1 Muaro Jambi
}

\author{
Emriyasmen \\ Sekolah Menengah Atas Negeri 1 Muaro Jambi
}

Abstract: The primary purpose of this study is to improve students' knowledge in planning, actuating, and reporting of art exhibition for students in class XI MIPA5 SMAN 1 Muaro Jambi. This study employs the classroom action research in two cycles with demonstration methods. Based on the study, student's knowledge in planning, actuating, and reporting of art exhibition increases in each cycle and raises the limit points determined.

Keywords: Students' knowledge, demonstration method, Art exhibition

\section{Pendahuluan}

Pameran merupakan kegiatan yang dilakukan untuk menyampaikan ide atau gagasan perupa kepada publik melalui media karya seninya. Melalui kegiatan ini diharapkan terjadi komunikasi antara perupa yang diwakili oleh karya seninya dengan apresiator. Hal ini sejalan dengan definisi yang diberikan Galeri Nasional bahwa: "Pengertian pameran adalah suatu kegiatan penyajian karya seni rupa untuk dikomunikasikan hingga dapat diapresiasi oleh masyarakat luas."

Penyelenggaraan pameran dalam konteks pembelajaran seni budaya bisa dilakukan baik di sekolah maupun di luar sekolah (masyarakat). Penyelenggaraan pameran di sekolah menyajikan materi pameran berupa hasil studi para siswa dari kegiatan pembelajaran 
Emriyasmen

kurikuler, dan kegiatan ekstrakurikuler. Kegiatan ini biasanya dilakukan pada akhir semester atau akhir tahun ajaran. Adapun konteks pameran dalam arti luas, di masyarakat, materi pameran yang disajikan berupa berbagai jenis karya seni rupa untuk diapresiasi oleh masyarakat luas.

Materi pameran seni rupa adalah materi yang disajikan di semester genap kelas XI di sekolah menengah atas negeri 1 Muaro Jambi yang meliputti pemahaman tentang perencanaan, pelaksanaan, pelaporan dan proses kegiatan pameran seni rupa yang diselenggarakan di sekolah. Pengetahuan siswa mengenai penyelenggaraan pameran terkait perencanaan, pelaksanaan, pelaporan serta proses kegiatan pameran sebelum dilakukan tindakan belum mencapai nilai minimal belajar yaitu 70, dan persentase rata-rata pengetahuan siswa kurang dari $25 \%$. Oleh karena itu penelitian ini bertujuan untuk meningkatkan pengetahuan siswa mengenai penyelenggaraan pameran karya seni rupa siswa kelas XI MIPA5 di SMAN I Pijoan Muaro Jambi.

\section{Landasan Teori}

\section{Pameran Seni Rupa}

Sebagai mahluk yang berakal dan berbudi, setiap pekerjaan yang kita lakukan seharusnya memiliki tujuan dan manfaat yang diharapkan serta dilakukan dengan penuh tanggung jawab. Dalam penyelenggaraan pameran setidaknya dikenal beberapa tujuan yaitu (1) tujuan sosial dan kemanusiaan, (2) tujuan komersial, dan (3) tujuan yang berkaitan dengan pendidikan. 
Kegiatan pameran karya seni rupa ini memiliki fungsi utama sebagai alat komunikasi antara pencipta seni (seniman) dengan pengamat seni (apresiator). Pameran seni rupa pada hakekatnya berfungsi sebagai pembangkit apresiasi seni pada masyarakat, di samping sebagai media komunikasi antara seniman dengan penonton.

\section{Jenis-Jenis Pameran}

Berdasarkan waktu penyelenggaraannya, pameran bisa dibedakan menjadi 3 jenis, yaitu: 1) Pameran periodik, yaitu pameran yang diselenggarakan secara teratur dalam waktu tertentu, misalnya sebulan sekali atau setahun sekali; 2) Pameran insidental, yaitu pameran yang diselenggarakan jika diperlukan, sehingga waktunya tidak bisa ditentukan; 3) Pameran permanen, yaitu pameran yang diadakan dengan tempat yang tetap dan dibuka dengan waktu yang telah ditentukan.Sedangkan pameran yang sifatnya untuk meningkatkan prestasi disebut dengan pameran studi.

Pameran studi dibedakan menjadi 4 jenis, yaitu: Pameran seniman, yaitu pameran yang diselenggarakan oleh seorang seniman atau beberapa orang seniman (kelompok seniman); Pameran keliling, yaitu pameran yang diselenggarakan jika diperlukan (pameran insidental) yang biasanya bertempat di luar sekolah atau tempat umum.; Pameran sekolah, yaitu pameran yang diselenggarakan secara periodik. Biasanya di kelas, aula sekolah, atau ruang kesenian.; dan Pameran kelas, yaitu pameran yang dilaksanakan setelah siswa selesai berkarya dari suatu tugas guru atau pada jam pelajaran apresiasi.

\section{Unsur-Unsur Perlengkapan Pameran Seni Rupa}


Emriyasmen

Unsur-unsur perlengkapan dalam pameran seni rupa sebagai berikut:

1. Karya-karya seni rupa yang akan dipamerkan;

2. Panel atau sketsel, standart display atau box, untuk memajang karya seni yang akan dipamerkan;

3. Dekorasi, yaitu perlengkapan untuk menyajikan karya seni agar lebih indah;

4. Sound system, yaitu sarana audio yang diperlukan untuk menciptakan suasana nyaman bagi pengunjung pameran;

5. Label karya, digunakan untuk menulis identitas (judul, pencipta, teknik, dan tahun penciptaan) dan ditempel di dekat karya seni yang dipamerkan;

6. Katalog, yaitu lembaran petunjuk yang berisi penyelenggaraan pameran;

7. Buku tamu, yang diisi oleh pengunjung pameran;

8. Buku pesan atau kesan, digunakan untuk mengetahui tanggapan pengunjung terhadap karya yang dipamerkan.

\section{Fungsi Pameran Seni Rupa}

Pameran mempunyai fungsi sosial yang sangat penting dalam upaya meningkatkan dan memenuhi kebutuhan batil dan emosional masyarakat, adapun fungsi pameran seni rupa berikut ini.

\section{Sarana Edukasi}

Pameran mendidik siswa akan pentingnya pengalaman batin yang berguna untuk menyeimbangkan kegiatan akal dan pikiran manusia. 
2. Sarana Apresiasi

Apresiasi dalam menilai karya seni sangat penting bagi pencipta karya tersebut. Proses apresiasi dapat digunakan menjadi 2, yaitu apresiasi aktif dan apresiasi pasif.

\section{Sarana Prestasi}

Pameran bisa menjadi ajang kompetisi bagi para pencipta seni, karena melalui karya seni kita akan tahu setinggi apa keaktifan dan kreativitas pencipta seni dalam membuat karya.

\section{Sarana Rekreasi}

Rutinitas sekolah kita setiap hari tentu menguras energi dan pikiran. Untuk membuat pikiran rileks kita bisa mengunjungi pameran seni.

\section{Tujuan Pameran Seni Rupa}

Pameran di sekolah mempunyai beberapa tujuan, seperti tujuan sosial, komersial, dan kemanusiaan, berikut penjelasan masing-masing tujuan tersebut:

a. Tujuan sosial, yaitu karya seni yang dipamerkan digunakan untuk kepentingan sosial.

b. Tujuan komersial, yaitu pameran bertujuan untuk menghasilkan keuntungan bagi seniman atau penyelenggara seniman. Diharapkan karya yang dipamerkan terjual.

c. Tujuan kemanusiaan, yaitu demi kepentingan pelestarian, pembinaan nilai-nilai, serta pengembangan hasil karya seni budaya yang masyarakat miliki. Penjualan karya dengan tujuan 
Emriyasmen

ini akan disumbangkan ke panti asuhan, korban bencana, maupun masyarakat kurang mampu.

\section{Metode Demonstrasi}

Metode pembelajaran adalah cara yang digunakan untuk melakukan aktivitas yang tersistem dan terstruktur dalam kegiatan pembelajaran yang dilakukan oleh pendidik agar tujuan pembelajran dapat tercapai secara efektif dan efisien sesuai dengan rancangan dan rumusan yang telah ditetapkan oleh pendidik.

Metode demonstrasi adalah metode pembelajaran dengan memperagakan sesuatu atau urutan melakukan kegiatan baik secara langsung maupun penggunaan media pengajaran yang relevan dengan pokok bahasan (Mudlofir \& Rusyidiyah, 2016, p.108). Lebih lanjut, metode demonstrasi merupakan pembelajaran dengan menggunakan atau menunjukkan cara kerja kegiatan yang berkenaan dengan bahan pelajaran.

Menurut (Mudlofur dan Rusyidiyah, 2016, p.108), demonstrasi dalam metode demonstrasi terdiri atas 4 bagian yaitu:

1) Demonstarsi proses, yaitu untuk memahami langkah-langkah dalam pokok bahasan yang akan dikaji;

2) Demonstrasi hasil sebagai suatu bentuk kegiatan yang menunjukkan pada kegiatan langsung atau praktek yang dilakukan oleh peserta didik.

Langkah-langkah yang dilakukan dalam metode demonstrasi menurut Sanjaya dalam (Mudlofir dan Rusyidiyah 2016, p.110-111): 
1. Tahap persiapan, meliputi:

a. perumusan tujuan yang harus dicapai setelah proses pembelajaran berakhir;

b. Mempersiapkan garis besar langkah-langkah demonstrasi yang akan dilakukan

c. Melakukan ujicoba untuk memantapkan persiapan sebelum demonstrasi.

2. Tahap pelaksanaan, terdiri atas:

a. Tahap persiapan; pengaturan posisi duduk peserta didik, pemberian introduksi awal tentang tujuan pembelajaran serta pemberian tugas yang akan dilakukan peserta didik

b. Tahap pelaksanaan demonstrasi: pemberian kegiatan yang merangsang peserta didik untuk berpikir, kesempatan peserta didik untuk aktif dalam kegiatan dan melakukan percobaan.

c. Tahap akhir yaitu memberikan tugas tertentu sesuai dengan pelaksanaan demonstrasi dan penyampaian tujuan pembelajaran

\section{Metode}

Penelitian ini menggunakan penelitian tindakan kelas (Classroom Action Research) karena penelitian ini bertujuan untuk meningkatkan kemampuan siswa dan memberikan kontribusi yang sangat berarti bagi guru dalam melaksanakan kegiatan belajar mengajar sehingga tujuan pembelajaran dapat tercapai secara maksimal. Penelitian tindakan kelas menurut Kemmis dan Taggart dalam Cohen, (Manion dan Morisson, 2000, p.277) adalah suatu bentuk penyelidikan 
Emriyasmen

reflektif diri yang bersifat kolaboratif yang dilakukan oleh semua yang terlibat dalam situasi sosial agar meningkatkan rasionalitas dan keadilan sosial itu sendiri atau praktek pendidikan, serta memahami tentang praktek dan keadaan dimana praktek itu dilakukan. Sehingga dapat dikatakan bahwa penelitian tindakan kelas adalah sebuah pendekatan penelitian untuk meningkatkan pendidikan melalui perubahannya dan belajar dari konsekuensi perubahan tersebut.

Penelitian ini dilakukan di kelas XI MIPA 5 Sekolah Menengah Atas Negeri (SMAN) 1 Muaro Jambi, terhadap 32 peserta didik semester genap, yang dilaksanakan pada bulan Januari sampai Februari 2020. Penelitian ini disusun berdasarkan langkah-langkah metode demonstrasi dengan instrument penelitian berupa RPP, lembar observasi siswa dan pendidik. Adapun siklus dalam penelitian ini menggunakan siklus penelitian tindakan kelas yang telah dikemukakan oleh Kemmis dan Taggart yaitu:

\section{Siklus I}

1. Perencanaan tindakan meliputi:

a. Penyusunan RPP dengan menggunakan metode demonstrasi;

b. Menyiapkan lembar pengamatan siswa dan pengamatan guru.

c. Lembar pengamatan siswa terdiri atas pengetahuan terkait perencanaan, pelaksanaan, dan pelaporan penyelenggaraan pameran seni rupa. Tabel 1 menyajikan lembar pengamatan peserta didik

d. Lembar pengamatan Pendidik terdiri atas Aspek Pendahuluan, Kegiatan Inti dan Penutup yang tersaji pada tabel 2. 
2. Pelaksanaan tindakan

a. Mempersiapkan waktu 2 kali pertemuan dalam setiap siklus.

b. Mengatur posisi duduk peserta didik

c. Memberikan instruksi awal terkait praktek kegiatan pameran seni rupa;

d. Merangsang peserta didik untuk berpikir dengan engajukan pertanyaan "pernahkah siswa mengunjungi kegiatan pameran seni rupa?" dan "bagaimana penyelenggaraan pameran seni rupa".

3. Observasi

Kegiatan observasi dilakukan bersamaan dengan kegiatan pelaksanaan tindakan. Kegiatan ini dilakukan oleh teman sejawat yang ditunjuk. Pada tahap ini peneliti dan teman sejawat mengamati dan mendokumentasikan seluruh perubahan yang terjadi dalam proses pembelajaran. Pada tahap observasi yang dilaporkan adalah ketepatan rancangan yang dipersiapkan, pelaksanaan tindakan pembelajaran dan kendala yang dihadapi oleh peneliti dan siswa. Hasil dari observasi ini berupa penilaian tentang pemahaman peserta didik terkait penyelenggaraan pameran pelaksanaan penyelenggaraan pameran seni rupa

\section{Refleksi}

Pada tahapan ini peneliti merangkum data, mereduksi data mengelompokkan, menyisihkan data yang tidak relevan, membuat kode-kode data yang jelas dan membuat kesimpulan. Selanjutnya, peneliti secara holistik mengkaji keberhasilan, kegagalan, kendala dan membuat konsep tindakan lanjut untuk mencapai tujuan penelitian yang akan dilaksanakan pada siklus II. 
Emriyasmen

\section{Siklus II}

Siklus kedua disesuaikan dengan hasil siklus pertama dan waktu yang tersedia. Hasil tindakan yang diharapkan dalam penelitian ini adalah meningkatkan pengetahuan siswa dalam pameran senirupa terkait perencanaan, pelaksanaan dan pelaporan.

\section{Hasil}

\section{Siklus Pertama}

\section{Pelaksanaan}

Berdasarkan refleksi awal pengetahuan siswa kelas X1MIPA5 SMAN I Muaro Jambi terkait perencanaan, pelaksanaan, dan pelaporan kegiatan pameran belum mencapai nilai pengetahuan yang diharapkan yaitu 30. Siswa masih belum memahami perencanaan, pelaksanaan, dan pelaporan kegiatan pameran terlihat dari nilai ideal yang hanya mencapai 24, 39. Oleh karena itu, metode demonstrasi yang digunakan dalam siklus pertama ini adalah dengan menerapkan langkah-langkah metode demonstrasi yang telah dikemukakan pada landasan teori di atas.

Pada siklus pertama ini, penulis memulai dengan mengajukan pertanyaan yang berkaitan dengan materi pembelajaran yaitu "pernahkan para siswa berkunjung pada kegiatan pameran seni rupa? dan diikuti dengan pertanyaan " bagaimana penyelenggaraan pameran senirupa?".

Pada siklus pertama, terlihat pengetahuan siswa terhadap penyelenggaraan pameran seni rupa masih belum mencapai nilai ideal yang diharapkan yaitu 30. Nilai ideal pengetahuan siswa hanya 
mencapai 26.11. Sedangkan berdasarkan hasil pengamatan terhadap pendidik terlihat nilai yang diperoleh masih dibawah 80 , yaitu sebesar 70. Terlihat. Pendidik dalam kegiatan pendahuluan masih kurang sempurna dalam melakukan dan pada kegiatan inti kurang sempurna dalam memberi siswa kesempatan untuk mencoba dan aktif melaksanakan tugas yang diberikan serta kurang sempurna dalam membimbing siswa dalam melakukan kegiatan penyelenggaraan pameran senirupa.

\section{Refleksi :}

Melihat hasil pengamatan siklus pertama, pendidik memperbaiki pada siklus II dengan memperbaiki pendahuluan dalam proses pembelajaran dan kegiatan inti serta membimbing siswa dalam kegiatan demonstrasi.

\section{Siklus kedua}

\section{Pelaksanaan}

Pada siklus II, pendidik memperbaiki semua kegiatan dalam proses pembelajaran sesuai dengan metode demonstrasi yang telah ditetapkan. Pendidik lebih memfokuskan pada pemberian kesempatan untuk siswa mencoba dan aktif dalam penyelenggaraan pameran senirupa serta membimbing siswa untuk melakukan kegiatan dengan totalitas. Sehingga, terdapat peningkatan yang signifikan dalam siklus II.

Nilai pengetahuan siswa tentang perencanaan, pelaksanaan, dan pelaporan penyelenggaraan pameran seni rupa meningkat sebesar 5.33 poin, yaitu dari 26.11 poin menjadi 31.44. Peningkatan ini, telah memenuhi standar nilai pengetahuan yang telah ditetapkan sebesar 30 . 
Emriyasmen

Sedangkan berdasarkan lembar pengamatan pendidik, peningkatan mencapai poin 30 menjadi 100 .

\section{Refleksi}

Berdasarkan hasil dari siklus II, maka pemberian tindakan dinyatakan telah cukup, sehingga upaya meningkatkan pengetahuan siswa dalam penyelenggaraan pameran senirupa telah memnuhi nilai pengetahuan yang diharapkan.

\section{Pembahasan}

Metode Demonstrasi merupakan metode dalam pembelajaran untuk dapat meningkatkan pengetahuan siswa terhadap pokok bahasan penyelenggaraan pameran senirupa mulai dari perencanaan, pelaksanaan, dan pelaporan, karena metode ini memperlihatkan bagaimana suatu proses atau urutan suatu kegiatan dilakasanaka (Mudlofir \& Rusydiyah, 2016, p.90). Sehingga. Siswa dapat memahami bagaimana perencanaan dalam penyelenggaraan pameran senirupa mulai dari pembentukan panitia, memilih orang tepat dalam kepanitiaan, membuat proposal pameran, tema, tujuan dan kurator pameran. Sebelum dilakukan tindakan kemampuan pengetahuan siswa tentang perencanaan penyelenggaraan pameran senirupamasih dibawah standar pengetahuan yang diharapkan yaitu sebesar 24. 23; dan pada saat dilakukan tindakan yaitu pada siklus pertama poin nilai pengetahuan terhadapa perencanaan penyelenggaraan pameran senirupa meningkat menjadi 27.10

Selanjutnya pada langkah pelaksanaan dan pelaporan pengetahuan siswa meningkat setelh dilakukan tindakan. Berdasarkan hasil prasiklus, siklus I, dan siklus II terdapat peningkatan pengetahuan siswa tentang pelaksanaan dalam penyelenggaraan pameran senirupa 
yaitu penataan ruangan, pengaturan lampu sorot, pengelompokkan karya seni, suhu ruang, sound system buku tamu, susunan acara pembukaan dan lainnya meningkat, secara berurutan adalah sebagai berikut $24.75 ; 25$. 85, dan 31.40 . Terkait pelaporan secara signifikan mengalami peningkatan. Gambar 1 menunjukkan peningkatan pengetahuan siswa terhadap penyelenggaraan pameran senirupa.

\section{Gambar 1. Peningkatan Nilai Pengetahuan Penyelenggaraan}

Pameran Seni rupa

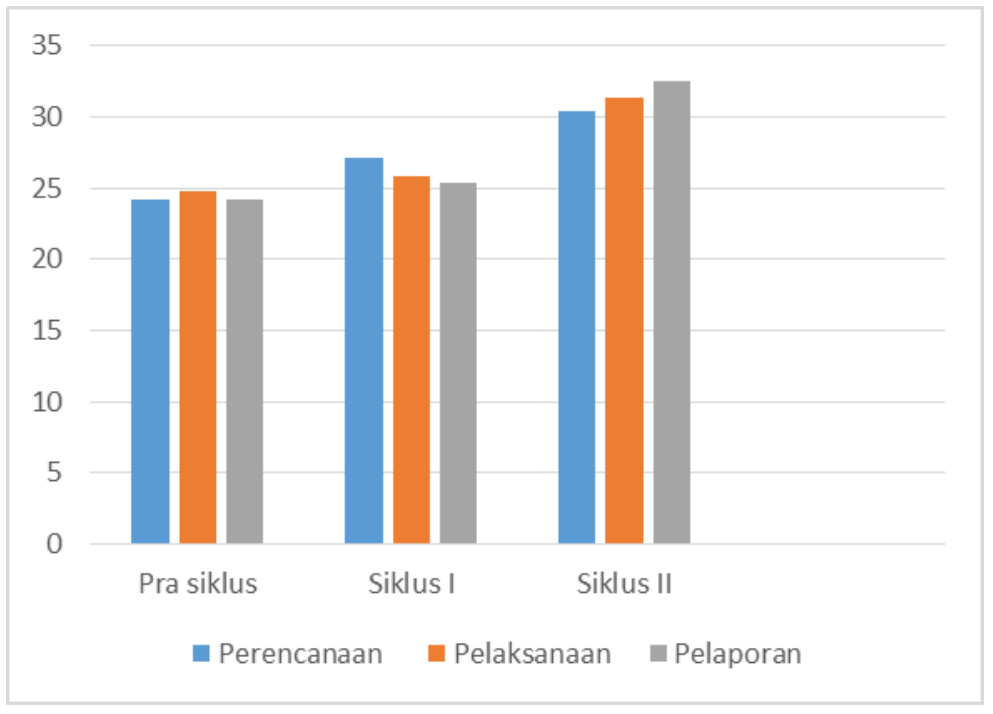

\section{Kesimpulan}

Berdasarkan uraian di atas, maka dapat disimpulkan bahwa penggunaan metode demonstrasi dapat meningkatkan pengetahuan siswa dalam pokok bahasan penyelenggaraan pameran senirupa. 


\section{Daftar Rujukan}

Cohen. L., Manion. L., \& Morrison. K. 2000. Research methods in Education, $5^{\text {th }}$ Edition. London: RoutledgeFalmer.

Daryanto. 2014. Pendekatan Pembelajaran Saintifik Kurikulum 2013. Yogyakarta: Gava Media.

Kemp dan Dayton diakses dari www.asikbelajar.com/2013/09/pengertian-manfaat-jenisdan-pemilihan.html pada tanggal 17 November 2019.

Kementerian Pendidikan dan Kebudayaan Republik Indonesia, Seni Budaya SMA/MA/SMK/MAK, (Jakarta: Kemendikbud, 2014).

Mudlofir, A., \& Rusydiyah, F.E. 2016. Desain Pembelajaran Inovatif: Dari Teori ke Praktek. Jakarta: PT RajaGrfaindo Persada.

Murhono. 2015. Peningkatan Hasil Belajar Seni Rupa pada Materi Gambar perspektif dengan memanfaatkan media pembelajaran fotografi di kelas XII IPA 5 SMAN 1 Pemalang Tahun Pelajarn 2012/2013, Elementary Journal Vol.3 Nomor 2, Juli Desember 2015.

Sadiman, Arief S. 2008. Media Pendidikan, Pengertian, Pengembangan, dan Pemanfaatannya. Jakarta: PT. Raja Grafindo Persada.

Sanjaya, Wina. 2008. Pedoman pengajaran bidan seni dan TK. Jakarta:

Sri Rakhmawati, Keefektifan penggunaan media gambar peristiwa dalam meningkatkan keterampilan menulis puisi pada siswa kelas VII SMP N 4 Depok, Yogyakarta. Skripsi Universitas Negeri Yogyakarta. Diakses dari google.com pada tanggal 17 Februari 2018.

Wajdi, Fathullah. 2017. Implementasi Project Based Learning (PBL) dan Penilaian Autentik dalam Pembelajaran Drama Indonesia, Jurnal Pendidikan Bahasa dan Sastra. Vol. 17, No 1. Hal.8177. Doi. http://dx.doi.org/10.17509/bs_jpbsp.v17i1.6960. 